\title{
INTERNATIONALIZED PRODUCTION IN DEVELOPED AND DEVELOPING COUNTRIES AND IN INDUSTRY SECTORS
}

Robert E. Lipsey

Working Paper 6405 
NBER WORKING PAPER SERIES

\title{
INTERNATIONALIZED PRODUCTION IN DEVELOPED AND DEVELOPING COUNTRIES AND IN INDUSTRY SECTORS
}

\author{
Robert E. Lipsey
}

Working Paper 6405

http://www.nber.org/papers/w6405

\author{
NATIONAL BUREAU OF ECONOMIC RESEARCH \\ 1050 Massachusetts Avenue \\ Cambridge, MA 02138 \\ February 1998
}

I am indebted to the staff of the International Economics Department of the World Bank for assistance with data for an earlier version of this paper. Ewa Wojas provided research and computer assistance for the present version. Any opinions expressed are those of the author and not those of the National Bureau of Economic Research.

(C) 1998 by Robert E. Lipsey. All rights reserved. Short sections of text, not to exceed two paragraphs, may be quoted without explicit permission provided that full credit, including $\odot$ notice, is given to the source. 
Internationalized Production in Developed

and Developing Countries and in Industry Sectors

Robert E. Lipsey

NBER Working Paper No. 6405

February 1998

\section{$\underline{\text { ABSTRACT }}$}

Internationalized production, that is, production in a country controlled by firms based in another country, grew from about 41/2 percent of world output in 1970 to over 7 percent in 1995. The importance of internationalized output fell substantially in developing countries until around 1990 but has been increasing since then, especially in the "transition" countries, where it has grown from less than \$100 million in 1977 to over \$25 billion in 1994.

The petroleum sector was the one with the highest share of internationalized production in the 1970s, but that share has declined sharply, especially in the developing countries, where important operations were nationalized. Manufacturing is now the sector in which internationalized production plays the largest role, the internationalized share rising from under 12 percent to more than 16 percent in 1990. That share was probably considerably larger in 1995, given the increase in the absolute value of internationalized output by more than a third from 1993 to 1995 .

Outside of petroleum and manufacturing, internationalized production was of little importance. For the world as a whole, the internationalized share was about 31/2 percent in 1990. However, if the trend in U.S.-owned production is an indication, the role of internationalized production in this sector may be changing; the share in total production of U.S. foreign affiliates in developing countries of a broad service sector including trade and finance rose from 6 percent in 1977 to 18 percent in 1995 .

Robert E. Lipsey

National Bureau of Economic Research

50 East 42nd Street, 17th Floor

New York, NY 10017-5405

relqc@cunyvm.cuny.edu 
Internationalized Production in Developed and Developing Countries and in Industry Sectors

\section{Introduction}

Many different measures have been used to describe the importance of the internationalization or "globalization" of production in the world economy, production in one country by firms based in another country, arising from direct foreign investment by home country firms in operations in a host country. Since flows of such direct investment are part of almost every country's balance of payments accounts, these are the most frequently cited measures of internationalization, along with stocks of direct investment, usually derived by cumulating the flows over time. Even if these data were accurate, it is not obvious what they should be compared to in order to judge the importance of the phenomenon they represent; there is no obvious denominator to compare them with. They are sometimes compared with host country or home country GDP, but since they are not part of GDP, it is not clear what a ratio between the two concepts means. Furthermore, the flows are identified by the country of immediate, rather than ultimate, ownership, so that it is not clear what country is the real source of the flow. Countries differ in their treatment of retained corporate earnings, with the result that data are not comparable across countries. The stock measures derived from flows ignore the effects of exchange rate fluctuations, of price changes, and often of retained earnings.

An earlier paper (Lipsey, Blomström, and Ramstetter, 1998) measured the share of internationalized production in world output. In this paper, the estimates are extended to 1995 and allocated by type of host country (developed vs. developing) and by broad industrial sector.

The measure of production used here is value added, or gross product originating. In measuring internationalization, the denominators are GDPs for the countries involved or value 
added or gross product originating in a sector or an industry and the numerators are value added or gross product in the foreign affiliates of a home country or the foreign-owned firms within a host country.

Unfortunately, there are only three countries that provide data on gross product or value added for their firms' foreign affiliates, or the materials needed to calculate them, the United States, Sweden, and Japan, and the Japanese data suffer from many defects that affect all their data for foreign affiliates, not just those for value added. Germany collects data on sales by its firms' foreign affiliates, which we use here to make very rough estimates of value added. There are more sources of data on value added from the host country side because a number of countries have coded their industrial censuses, or at least their manufacturing censuses, to distinguish establishments controlled by foreign firms from those controlled domestically. This coding permits the calculation of value added in foreign controlled, or internationalized, production within the country

These gross output measures have their own defects, even though they are the most satisfactory for our purpose. Since profits are a large part of gross output, the figures tend to be volatile, a particular problem if one is trying to discern trends from data that are not available annually, as is generally the case. In addition, for the countries that report only sales, it is necessary to assume that value/sales ratios are constant and are not affected by changes in the composition of production, something we know from the U.S. data is not true. For example, the ratios are much higher in manufacturing than in trade affiliates. 


\section{Internationalized Production in World Output}

The main trends in the importance of internationalized production are summarized in Table 1. Internationalized production by firms based in the United States, Germany, Japan, and Sweden, the countries for which we have such data, grew from $2 \& 1 / 2$ per cent of world output in 1970 to a little over 3 per cent in 1977, and $3 \& 1 / 2$ per cent in 1995 .

It is clear, if one judges by data on the nominal stock of outward direct investment, that the role of these four countries in total world investment has been declining steadily, at least over the last 20 years or so. If we assume that the share of these four countries' firms in world output is proportional to, or moves in parallel with, their countries' share of direct investment stocks, we can estimate the trend in the internationalized production share of world output, as in column 3 of Table 1. That share has been increasing, from about $4 \& 1 / 2$ per cent in 1970 to around 6 per cent in 1990-1992, and to over 7 per cent in 1994 and 1995.

These aggregate shares of internationalized production may seem surprisingly small in view of the extent of discussion of "globalization." One reason is the concentration of this production and of direct investment in two highly visible and closely watched sectors: manufacturing and petroleum. In the United States, for example, they accounted in 1994 for 18 per cent of total domestic output but they accounted for almost three quarters of production by U.S. affiliates abroad. U.S.-owned internationalized production was about equal to home production in petroleum, and 17 per cent as large as home production in manufacturing, but less than 2 per cent as large in all other industries combined. Thus, despite the recent surge in public utility and telecommunications investment, internationalized production remains very largely a phenomenon of the mining and manufacturing sectors and a minor part of the much larger service sector. 
TABLE 1

ESTIMATE OF INTERNATIONALIZED PRODUCTION FROM THE HOME-COUNTRY SIDE

\begin{tabular}{cccc}
\hline & $\begin{array}{c}\text { AFFILIATE (INTERNATIONALIZED) } \\
\text { OUTPUT OF FIRMS FROM FOUR } \\
\text { HOME COUNTRIES } \\
\text { OF WORLO } \%\end{array}$ & $\begin{array}{c}\text { SHARE (X) OF FOUR HOME } \\
\text { COUNTRIES IN WORLD STOCK } \\
\text { OF OUTWARD FDI }\end{array}$ & $\begin{array}{c}\text { SHARE OF INTERNATIONALIZED } \\
\text { OUTPUT IN WORLD GDP " }\end{array}$ \\
\hline 1970 & 2.5 & & \\
1977 & 3.1 & $(55)$ & 4.5 \\
1982 & 3.2 & $(57)$ & 5.4 \\
1990 & 3.0 & $(55)$ & 5.8 \\
1992 & 3.1 & 50 & 6.0 \\
1993 & 3.2 & 50 & 6.2 \\
1994 & 3.4 & 49 & 6.5 \\
1995 & 3.5 & 47 & 7.2 \\
1996 & & 48 & 7.3 \\
\hline
\end{tabular}

US, Japan, Germany, and Sweden

${ }^{\mathrm{b}}$ Figures in parentheses are straight - line interpolations from estimates for 1960, 1975, 1980 and 1985 , from Lipsey, Blomström, and Ramstetter (1998) and later years from UN volumes.

'Including four countries. (Calculated as (col.1:col.2)*100.

${ }^{d}$ Rough estimates

Source: Appendix Tables A-1, C-2, Lipsey, Blomström, and Ramstetter (1998), United Nations (1997) annex table 4 


\section{Internationalized Production in Developing Country Output}

The share of internationalized production in developing countries can be estimated in more or less the same way as for the world as a whole. One advantage of the developing country data is that the four investing countries for which we have data, the United States, Japan, Germany, and Sweden, account for a larger proportion of the total foreign direct investment in these countries than in developed countries, ranging from 62 to 68 per cent during the 1990s. There is, therefore, less room for errors from adding the non-reporting countries. On the other hand, the GDP estimates for the developing countries and the conversions into U.S. dollars via exchange rates are more questionable than those for the world, dominated by the figures for the developed countries.

The proportions of direct investment stocks in developing countries owned by the four home countries we cover has ranged since 1970 from a little under half to over 60 per cent, and even as high as two thirds outside the "formerly planned" or "transition" economies (Appendix Table B-7). It appears that the four-country share has fallen somewhat during the 1990s, but the figures are not reliable enough to inspire confidence in that judgment. These estimated fourcountry shares are used in Table 2 , together with estimates of production by affiliates of firms from these countries, to calculate the internationalized shares of output in developing countries. Those shares, aside from the earliest one excluding the planned economies, seem to have been considerably below the shares for the whole world shown in Table 1, and by implication, below the ratios in developed countries. Whether we use UN or World Bank figures for total output in developing countries, it appears that the trend in the internationalized share was downward until about 1990, but has turned around since then. The recent shares are beginning to look more like those for the world as a whole, at least outside the transition economies. However, the upward 


\section{TABLE 2}

\section{ESTIMATE OF INTERNATIONALIZED PRODUCTION IN DEVELOPING COUNTRIES FROM THE HOME COUNTRY SIDE}

\begin{tabular}{|c|c|c|c|c|c|c|c|c|c|c|}
\hline & \multicolumn{5}{|c|}{ ALL DEVELOPING COUNTRIES } & \multicolumn{5}{|c|}{ DEVELOPING COUNTRIES EXCLUDING TRANSITION ECONOMIES } \\
\hline & \multirow{3}{*}{$\begin{array}{l}\text { OUTPUT OF MNCS: } \\
\text { SMHLLON US }\end{array}$} & \multicolumn{2}{|c|}{ TOTAL OUTPUT } & \multicolumn{2}{|c|}{ MNC SHARE } & \multirow{3}{*}{$\begin{array}{l}\text { OUTPUT OF MNC: } \\
\text { SMLUNON US } \\
\end{array}$} & \multicolumn{2}{|c|}{ TOTAL OUTPUT } & \multicolumn{2}{|c|}{ MNC SHARE } \\
\hline & & UN & WORLD BANK & UN & WORLO BANK & & UN & WORLD BANK & un & WORLD BANK \\
\hline & & SBiL & LION US & & RCENT & & $S B A$ & N US & & ENT \\
\hline 1977 & 136,943 & 2,606 & & 5.25 & & 136,875 & 1,520 & & 8.97 & \\
\hline 1982 & 140,711 & 4,116 & & 3.42 & & 139,149 & 2,632 & & 5.29 & \\
\hline 1990 & 190,342 & 6,618 & 4,923 & 2.88 & 3.87 & 183,524 & 4,174 & 3,308 & 4.40 & 5.55 \\
\hline 1992 & 215,425 & 6,339 & 5,043 & 3.40 & 4.27 & 198,817 & 5,150 & 3,644 & 3.86 & 5.46 \\
\hline 1993 & 254,536 & & 5,053 & & 5.04 & 226,101 & & 3,762 & & 6.01 \\
\hline 1994 & 291,095 & & 5,391 & & 5.40 & 263,077 & & 4,096 & & 6.42 \\
\hline
\end{tabular}

- Four - Country output from Appendix Table C-3 divided by share of 4 countries' outward stock in reported total inward stock in all developing countries

Sources: Appendix Tables A-1, B-7, C-3, and United Nations (1995 b). 
trend clearly is strongest in the transition economies, and that growth accounts for much of the overall upward trend in developing countries as a group.

There are several elements in the calculation of the recent estimates of the internationalized share that may bias the trend upwards. One is the reported decline in GDP, translated by exchange rates into U.S. dollars, in the former Soviet Union and other "transition" economies. If their exchange rates have been falling faster than the internal purchasing power of their currencies, the declines in aggregate output, and the increases in the internationalized share of output, may be exaggerated. There may also be questions about the extent of the inflow into China and the size of the investment stock there, because of the role of "round trips" through Hong Kong that take advantage of incentives for foreign investors. Some unknown part of the inward investment stock and flow and of production arising from such practices would disappear if firms were classified as foreign- or domestically- owned according to the country of ultimate beneficial ownership rather than the country of immediate ownership. The use of immediate ownership may also inflate the regional Asian and world stocks of FDI if, for example, much of the investment in China is carried out by firms in Hong Kong that have already been counted as investments in Hong Kong from Taiwan or other countries.

The growth of internationalized production in developing countries since 1990 appears less rapid if we omit the "formerly planned" economies from the category. The difference is fairly small for production by firms from the United States (53\% vs. 58\% growth between 1990 and 1995), but much larger for firms from Germany (60\% vs. almost 100\% between 1990 and 1995), because production in the "reform" countries, mainly in Europe, rose from $4 \& 1 / 2$ per cent of German-owned output in developing countries in 1990 to over 23 per cent in 1995 (Appendix Table C-3). Unfortunately, we do not have the same output information for Japan. However, the 
data for investment stocks indicate that the transition economies accounted for less than 1 per cent of the Japanese outward investment stock in 1982, a little over 3 per cent in 1990, and $6 \& 1 / 2$ per cent in 1995.

The share of these four home countries' firms in developing country output outside the transition countries grew by only 16 per cent during the 1990 s; their share in the output of all developing countries rose by 40 per cent (Table 2 ).

These impressions about shares in developing country output can be tested against the independent, but still sketchy, data from the host country side. Those from a couple of combinations of these host countries suggested that there was something of a fall in the internationalized shares after 1977 , followed by an increase to about $3 \& 1 / 2$ per cent in 1990 , close to the estimate from the home country side of 3 to 4 per cent (Lipsey, Blomström, and Ramstetter, 1998). The story since then is uncertain because few of the countries have published up-to-date information.

One very strong trend is shown by the data for China, where the share of "industry" output produced by firms other than those in the state and collective sectors, mostly foreign owned firms, increased as shown below:

Share of "Industry" Output Produced by Firms

Other Than State and Collectively Owned

$\begin{array}{lrr} & \% & \\ 1990 & 4.4(\mathrm{a}) & \\ 1991 & 5.7(\mathrm{a}) & \\ 1992 & 7.1(\mathrm{a}) & \\ 1993 & 10.2(\mathrm{a}) & 12.9 \\ 1994 & & 15.9 \\ 1995 & & 19.7 \\ 1996(8 \text { mos. }) & & 21.2\end{array}$

(a) Other than state, collectively, or individually owned Source: China, State Statistical Bureau (Various Years). 
Although these numbers refer to the gross value of output rather than value added and to "Industry" rather than total output, when much of China's output is still in the agricultural sector, the internationalized sector is clearly reaching an important level. The gross value of output in 1994 of almost 850 billion yuan might be associated with about 300 billion in net output, if value added ratios are anything like those in other countries. That would have been in a year in which GDP was about 4.4 trillion yuan, implying that internationalized production had reached something in the neighborhood of 7 per cent of total national output, well above the share in most capitalist countries, especially large ones.

In contrast to the enormous changes in the role of internationalized production in China, the story for India, at least through 1990, was one of minimal importance and a static position. The share of such production in total output hardly varied from about $1 \& 3 / 4$ per cent from 1975 through 1990 and the share of foreign-owned manufacturing output in GDP remained close to $1 \& 1 / 4$ per cent. The foreign-owned share in manufacturing output itself was, if anything, declining. It had been at $7 \& 1 / 2$ per cent in 1975 and 7 per cent around 1980 , but did not reach as high as $6 \& 1 / 2$ per cent during the second half of the 1980 s (Lipsey, Blomström. and Ramstetter, 1998). Data on inflows and stocks of FDI during the 1990s suggest at least some reversal of this decline as India liberalized its rules on inward investment. Inflows grew to more than ten times their 1985-1992 level by 1996 and the inward stock grew to five times the 1990 level but, to put the numbers in some comparative perspective, it can be pointed out that the inward stock in 1996 was still only about a third of that in Hong Kong and five per cent of that in China (United Nations, 1997). 
Few observations are available for other developing Asian countries in the 1990s, but the initial ones do not show anything like the rate of growth observed for China. For the other countries there is a mixture of increases and decreases in the role of internationalized production. Given the large weight of China in the total of developing country GDPs, it is understandable why the internationalized share is rising for the group as a whole.

Another perspective on changes in the importance of internationalized production is given by U.S. affiliate shares in developing country output calculated by the U.S. Department of Commerce for 27 developing countries (Mataloni and Fahim-Nader, 1996). Between 1989 and 1994, the U.S. affiliate share rose in 13 countries, fell in 12, and remained constant in two. For a longer period, from 1982 to 1995, U.S. affiliate shares increased in 9 of the countries, remained constant in one, and decreased in 17 (Mataloni, 1997, p.56). These data confirm the impression that while there has been a rise in the share of internationalized production in aggregate world output, it is heavily concentrated in a fairly small number of countries.

\section{The Sectoral Distribution of Internationalized Production}

Data on internationalized production by sector are scarce and data by sector and region are even scarcer, but it is possible to draw some inferences about trends for three very broad sectors, manufacturing, primary production, or mining, including petroleum, and others, including all types of services. The last is most of world output and is a mixture of infrastructure services, such as electric power production and distribution and telecommunications, personal services, business services, such as the financial sector, and government services.

Some hint of the trend can be gleaned from the distribution of the stock of direct investment. The UN has calculated that the share of the primary sector in the outward investment of the largest home countries was 23 per cent in 1970 and 25 per cent in 1975 , but had fallen to 
11 per cent by 1990 . The primary share of the inward investment stock fell from 16 per cent to 9 per cent in developed host countries between 1975 and 1990 but in the same period stayed above 20 per cent in developing countries, first rising from 21 to 24 per cent by 1985 and then falling back to 22 per cent.

The United States is the only country for which we have production data for this sector, the main component of which is petroleum, but the output data combine the primary production part of the industry with refining and marketing, and therefore exaggerate the absolute and relative size of affiliate production. The importance of this industry in U.S.-owned foreign production was as follows, in per cent:

$\begin{array}{ll}1977 & 38 \\ 1982 & 38 \\ 1989 & 24 \\ 1991 & 25 \\ 1992 & 26 \\ 1993 & 26 \\ 1994 & 23 \\ 1995 & 22\end{array}$

Source: Mataloni and Goldberg(1994); Mataloni(1995) and (1997); and Mataloni and Fahim-Nader(1996).

This decline in importance took place despite the fact that, within the U.S. petroleum industry itself, foreign production in all petroleum-related activities increased from less than 60 per cent of domestic oil and gas extraction in 1982 to more than 100 per cent in 1994 (after the ratio was cut in half from 1977 to 1982 ).

Relative to world production in mining and quarrying, the U.S. petroleum industry's internationalized output fell from 23 per cent in 1977 to 18 per cent in 1990, but the change was much larger in developing countries, where the decline was from the same 23 per cent to 10 per cent (Mataloni and Goldberg, 1994, and United Nations, 1993). The fading of the role of U.S. 
internationalized production in this sector is exemplified by the declines in the U.S. affiliate production share between 1982 and 1995 in the United Arab Emirates from 10 per cent to 2.8 per cent and in Saudi Arabia from 3.3 per cent to 0.3 per cent (Mataloni, 1997, p.56).

The history of internationalized production in manufacturing is quite different, as far as we can tell with the meager data available. For this estimation we lack world totals for manufacturing gross output since 1990 and worldwide data on stocks of FDI in manufacturing. We assume that the shares in manufacturing FDI of the four countries for which we have production data are the same as their shares in total FDI. The results of this calculation are shown in Table 3.

The share of internationalized production in world manufacturing output is much higher than the share in total output. In 1990 it reached 16.3 per cent, about a 40 per cent increase over the 11.6 per cent of 1977 . Despite the declining role of manufacturing in the world economy, internationalized manufacturing output increased relative to total world output, from 2.3 per cent in 1977 and 1982 to around 3 per cent in 1989-1992, and to almost 4 per cent in 1994-95.

Outside of manufacturing and mining, internationalized production has played a small role. Firms from the United States, Japan, and Germany accounted for 1.7 per cent of world output in this group of sectors in 1990, 1.8 per cent outside of agriculture (Appendix Table C-10). If we assume the same importance for these home countries in the world total for this services, etc. sector as for total FDI, the implied trend in the internationalized share would be as follows:

$\begin{array}{ll}1977 & 2.3 \\ 1982 & 2.5 \\ 1989 & 3.1 \\ 1990 & 3.4\end{array}$

Thus there seems to be some indication of a rising trend up through 1990, although the shares remain small. 
TABLE 3

\section{AFFILIATE (INTERNATIONALIZED) \\ MANUFACTURING OUTPUT OF \\ FIRMS FROM FOUR \\ HOME COUNTRIES AS \% OF}

\begin{tabular}{llll}
\hline & WORLD MFG. GROSS OUTPUT & \multicolumn{2}{c}{ WORLD GDP } \\
\cline { 3 - 4 } & & UN & WORLD BANK \\
1977 & 11.6 & 2.3 & \\
1982 & 12.6 & & \\
1989 & 15.3 & 2.3 & \\
1990 & 16.3 & 2.9 & 3.0 \\
1991 & & 3.1 & 2.9 \\
1992 & & 3.1 & 3.2 \\
1993 & & 3.1 & 3.4 \\
1994 & & & 3.8 \\
1995 & & & 3.9 \\
\end{tabular}

SOURCE: Appendix Table C-5 
This is a very broadly defined sector, but for U.S. affiliates a further breakdown is possible from the same sources as for Appendix Table C-2. The largest component of this sector is wholesale trade, consisting mainly of the sales affiliates of U.S. manufacturing parent firms. The shares of these affiliates in total affiliate output ( in per cent) were:

$\begin{array}{rr}1977 & 7.01 \\ 1982 & 8.68 \\ 1989 & 11.86 \\ 1990 & 11.30 \\ 1991 & 11.53 \\ 1992 & 11.00 \\ 1993 & 11.43 \\ 1994 & 11.72 \\ 1995 & 12.05\end{array}$

The large increase in the importance of these affiliates took place between 1977 and 1989, with little change thereafter.

The finance (except banking) sub-sector's share in affiliate output was highly volatile, but larger in the 1990s than in 1977 and 1982. However, only after a 50 per cent increase in 1995 did it reach 3 per cent of U.S. affiliate production.

The steadiest rise in importance was for "Services," including a variety of business and personal services, ranging from hotels and restaurants to engineering and consulting services. The share of this group of services, in per cent, was:

$\begin{array}{ll}1977 & 2.43 \\ 1982 & 3.58 \\ 1989 & 4.56 \\ 1990 & 4.80 \\ 1991 & 5.08 \\ 1992 & 5.68 \\ 1993 & 5.99 \\ 1994 & 6.99 \\ 1995 & 7.28\end{array}$


This group of industries almost tripled in importance over this period, with an increase every year. If there is any current trend in the industry composition of U.S. firms' internationalized production, this seems to be it.

Trade affiliates have always been much more important as a part of Japanese FDI than of that of the United States or other countries. In 1980, they accounted for almost 60 per cent of production in Japanese foreign affiliates, both selling Japanese manufactures abroad and buying foreign products, especially raw materials, for the Japanese market. There importance has decreased since then, but they still were larger than Japanese manufacturing affiliates as foreign producers until 1992 ( Lipsey, Blomström, and Ramstetter, 1998, Table 5a). Production in Japanese trade affiliates has also been larger than in U.S. wholesale trade affiliates, in contrast to the situation in manufacturing and in FDI as a whole. The two countries' affiliates account for about $3 \& 1 / 2$ per cent of market economy gross output in Trade, suggesting that all internationalized production in this sector probably is roughly 7 per cent of the world total, with little change, or perhaps a slight increase since the late 1970s.

\section{Sectoral Composition in Developing Countries}

Only fragmentary data are available from the home-country side on the sectoral composition of production in developing countries, especially outside the distinction between manufacturing and other industry groups. For the mining industry, we can compare the output of U.S. petroleum industry affiliates with the total gross output of the mining and quarrying industry in developing countries. The share of the U.S. affiliates fell sharply, from 23 per cent in 1977 to less than 10 per cent in 1990 (Appendix Table C-7). Since that industry sector was at the same time becoming a smaller part of the total output of these countries, the share of U.S.-owned internationalized petroleum output in the aggregate output of developing countries fell even more, 
from almost 3 per cent to only about half of one per cent (Appendix Tables A-1, A-2, and C-7). Another way of describing the declining importance of the petroleum industry in U.S. affiliate production in developing countries is the fact that while the industry accounted for more than two thirds of all U.S.-owned production in these countries in 1977, its share was less than a quarter in 1995 (Appendix Tables C-3 and C-7).

Most of the declining share of the petroleum industry was taken up by manufacturing, the share of which in U.S.-owned developing country output rose from 22 per cent to almost a half in 1995 (Appendix Tables C-3 and C-8). Despite this rise, U.S. affiliates were responsible for a declining share of total manufacturing output in developing countries after a peak at a little under 6 per cent in 1982. In 1990 , U.S. manufacturing affiliates produced only $4 \& 1 / 2$ per cent of manufacturing output and less than 1 per cent of total output in these countries (Appendix Tables A-1, A-2, and C-8).

Data from the host country side do not suggest any rise of internationalized shares in developing country manufacturing during the 1980s. The two largest countries, India and China present contrasting pictures: little or no change in the foreign-owned share in India, at least up to 1990, and perhaps a decline from the 1970s levels, while in China there was a strong upward trend in the foreign share. As shown above, that rise in China accelerated greatly in the 1990s, but China does not seem to be at all typical of developing countries in this respect.

Although both agriculture and mining were far more important parts of aggregate output in developing countries than in developed countries (27 per cent of GDP as compared with 4 per cent in 1990 according to United Nations, 1993), they were declining sectors in both groups of countries. The manufacturing sector, in contrast, was declining in the developed countries but rising in importance, slowly, in developing countries, so that by 1990, its share in the latter group, 
at 19 per cent of GDP, was not far below the 23 per cent of the developed countries. The service sector, broadly defined to include all the others, was growing more important in both sets of countries, although the process had gone further by 1990 (73 per cent) in the developed countries than in the developing ones (58 per cent).

The growing importance of the service sector in developing countries' output had its counterpart in U.S. affiliate production in these countries. A "service" sector consisting of Wholesale trade, Finance, except banking, and Services, which accounted for 6 per cent of U.S. affiliate production in developing countries in 1977, was the source of 18 per cent of such production in 1995 (Mataloni, 1997). Despite the growth of this sector within U.S. affiliate output, internationalized production remained a very small part of host country output, which was also growing rapidly. From 1977 to 1990 , the share of U.S. affiliate production in developing country service sector output fell, from about $1 / 2$ of 1 per cent to $1 / 3$ of 1 per cent, and the share of the total GDP in these countries also fell (Appendix Tables A-1, A-2, and C-9). After 1990, the trend was reversed, and in the next five years, the share of internationalized service output in GDP in the developing countries more than doubled. However, the shares of internationalized production remain so small that they could not be important to the host economies in the aggregate for a long time. That is not to say that the internationalized production in the service sector may not be extremely important in particular activities, such as telecommunications, computer services, or tourism, but those roles cannot be studied using data for broad aggregates.

\section{Summary}

Internationalized production, defined as production by firms outside their home countries, is a better measure of the impact of direct investment than the more readily obtainable measures, such as FDI flows and stocks, exports, or affiliate sales. Such production is estimated to have 
increased from about $4 \& 1 / 2$ per cent of world output in 1970 to around $6 \& 1 / 2$ per cent in 19901993, and perhaps to $7 \& 1 / 2$ per cent in 1995 . It is concentrated in two sectors of the economy, petroleum and manufacturing, and accounts for much smaller fractions of the output of the broadly defined Service sector, which is the source of two thirds or so of world production. Internationalized production is less important in developing countries than in developed countries, but has been increasing rapidly since 1990 , mainly because of the rise in investment in the formerly planned economies, particularly China and, for Germany, Central and Eastern Europe. Outside of these countries, there does not appear to have been rapid growth of internationalized production in the developing countries.

The main change in the sectoral distribution of internationalized production has been the decline in the importance of the primary sector, particularly petroleum. Internationalized production plays a larger role in manufacturing than in most other sectors, about 16 per cent of the total in 1990 as compared with $11 \& 1 / 2$ per cent in 1977 , and internationalized manufacturing production has become larger relative to total world GDP despite the decline in the importance of the manufacturing sector. Internationalized production has also gained as part of the "Service" sector, consisting of all industries except manufacturing and mining, but the internationalized share remains small, only about $3 \& 1 / 2$ per cent. Within the subsector consisting of wholesale and retail trade the internationalized portion is larger, perhaps about 7 per cent, and has grown slowly, if at all. The trade sector has been becoming a larger part of U.S.-owned internationalized production but has declined from its former dominance in Japanese-owned production.

Within developing countries, the strongest trend has been the decline in the role of internationalized production in mining. The share of U.S.-owned production in manufacturing output in these countries has also fallen, but that of Japanese production and of German 
production has offset the decline of U.S. firms. The major growth in internationalized production in manufacturing seems to have been in China and in formerly planned economies in Europe, but there has so far been little change in other developing countries. There is some indication of growth in the role of internationalized production in developing country service sectors, but the shares are still small and will probably remain so. 


\section{$\underline{\text { References }}$}

Bach, Christopher L (1997), "U.S. International Transactions, First Quarter 1997," Survey of Current Business, Vol.77, No. 7, July, pp. 56-99.

Bargas, Sylvia (1997), "Direct Investment Positions for 1996: Country and Industry Detail," Survey of Current Business, Vol. 77, No. 7, July, pp.34-41.

Blomström, Magnus (1990), "Competitiveness of Firms and Countries" in John Dunning,

Bruce Kogut, and Magnus Blomström, Globalization of Firms and the

Competitiveness of Nations, Crafoord Lectures, 2, Lund, Lund University Press. and Robert E. Lipsey (1989a), "The Export Performance of Swedish and

U.S. Multinationals," Review of Income and Wealth, Series 35, No. 3, September. and (1989b), "U.S. Firms in Latin American Service

Industries," World Development, Vol. 17, No. 11. and (1993), "The Competitiveness of Countries and

their Multinational Firms, "in Lorraine Eden and Evan Potter (Eds.), Multinationals in the

Global Political Economy, London, Macmillan.

China, State Statistical Bureau (1993), Guangdong Tongji Nianjian (Statistical Yearbook of

Guangdong), Beijing, in Chinese.

(1994), Monthly Statistics, December.

(1995), Monthly Statistics, December.

(1996), Monthly Statistics, August.

Germany, Deutsche Bundesbank (1993), Kapitalverflechtung mit dem Ausland, June.

(1995), Kapitalverflechtung mit dem Ausland, May.

(1997), Kapitalverflechtung mit dem Ausland, May

India, Reserve Bank of India (1994a), Reserve Bank of India Bulletin. Vol.XIVIII, No. 8, August, Issued with Supplement. 
International Monetary Fund (1996), International Financial Statistics Yearbook, 1996,

Washington, D.C., International Monetary Fund, July. (1997), World Economic Outlook, May 1997, Washington, D.C., International Monetary Fund.

Kravis, Irving B., and Robert E. Lipsey (1992), "Sources of Competitiveness of the United States and of its Multinational Firms," Review of Economics and Statistics, Vol. LXXIV, No. 2, May.

Lipsey, Robert E. (1995), "The Transnationalization of Economic Activity," Report to the Division on Transnational Corporations and Investment, UNCTAD, Geneva, January. , Magnus Blomström, and Irving B. Kravis (1990), "R\&D by Multinational Firms and Host Country Exports," in Robert E. Evenson and Gustav Ranis (Eds.), Science and Technology: Lessons for Development Policy, Boulder and San Francisco, Westview Press. Magnus Blomström and Eric Ramstetter (1998), "Internationalized Production in World Output," in Robert E. Baldwin, Robert E. Lipsey, and J. David Richardson, Editors, Geography and Ownership as Bases for Economic Accounting, Studies in Income and Wealth, Vol. 59, Chicago, University of Chicago Press, forthcoming, 1998. and Irving B. Kravis (1985), "The Competitive Position of U.S. Manufacturing Firms," Banca Nazionale del Lavoro Quarterly Review, 153, June, pp. 127-154. (1987), "The Competitiveness and Comparative Advantage of U.S. Multinationals, 1957-1984," Banca Nazionale del Lavoro Quarterly Review, No. 161, June 1987.

Mataloni, Raymond J., Jr. (1995), "U.S. Multinational Companies: Operations in 1993," Survey of Current Business, Vol. 75, No, 6, June, pp. 31 - 51.

(1997), "U.S. Multinational Companies: Operations in 1995," Survey of Current Business, Vol. 77, No. 10, October, pp. 44-68. 
and Lee Goldberg (1994), "Gross Product of U.S. Multinational

Corporations, 1977-91," Survey of Current Business, Vol. 74, No. 2, February, pp. 42-63. and Mahnaz Fahim-Nader (1996), "Operations of U.S. Multinational

Companies: Preliminary Results from the 1994 Benchmark Survey," Survey of Current

Business, Vol. 76, No.12, December, pp. 11-37.

OECD (1982), Investing in Developing Countries: Fitth Revised Edition, Paris, November

(1993), International Direct Investment Statistics Yearbook, 1993_Paris.

(1996), International Direct Investment Statistics Yearbook, 1996, Paris

United Nations (1993), MSPA Handbook of World Development Statistics, Long-Term Socio-

Economic Perspectives Branch, Macroeconomic and Social Policy Analysis Division,

Department of Economic and Social Information and Policy Analysis, New York, United

Nations.

(1995b), Handbook of World Development Indicators, Projections and

Perspectives Studies Branch, Macroeconomic and Social Policy Analysis Division, Department of Economic and Social Information and Policy Analysis, New York, United Nations.

(1994), World Investment Report, 1994; Transnational Corporations,

Employment, and the Workplace, New York and Geneva, United Nations

(1995b), World Investment Report, 1995; Transnational Corporations and

Competitiveness, New York and Geneva, United Nations.

(1996), World Investment Report, 1996: Investment. Trade, and International

Policy Arrangements, New York and Geneva, United Nations.

(1997), World Investment Report, 1997; Transnational Corporations, Market

Structure, and Competition Policy, New York and Geneva, United Nations.

U.S. Department of Commerce (1981?), Selected Data on U.S. Direct Investment Abroad, 1966-

1978, Bureau of Economic Analysis, Washington, D.C.

(1996), "BEA Current and Historical Data," Survey of Current

Business, Vol. 76, No. 12, December, pp. D-1 to D-72. 
(1997), “ U.S. Direct Investment Abroad, Balance of Payments, and Direct Investment Position Estimates, 1982-1995," diskette. 
APPENDIX A

WORLD AGGREGATE DATA 


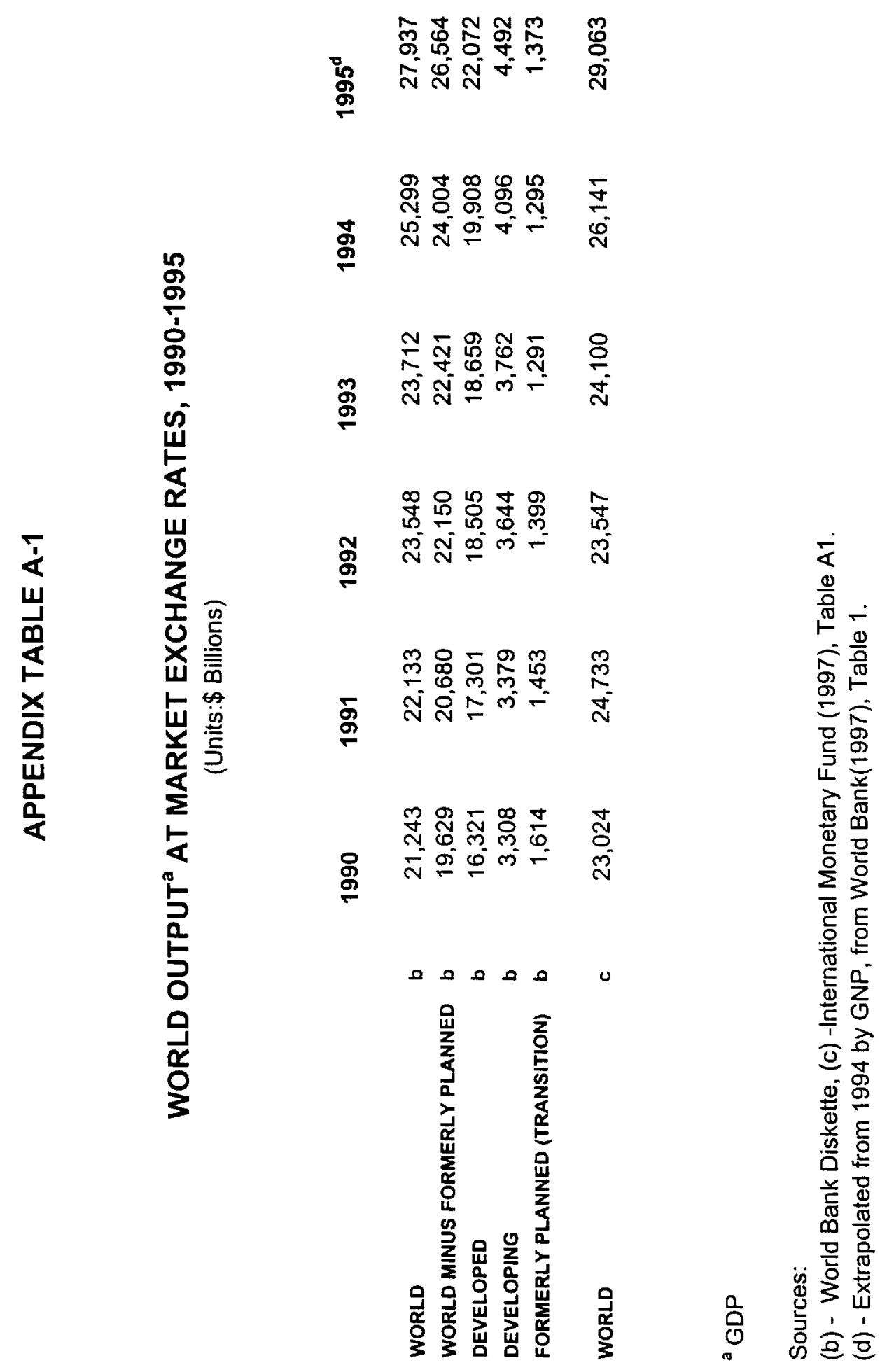




\section{APPENDIX TABLE A-2}

\section{GROSS PRODUCTOF MARKET ECONOMIES," BY BROAD PRODUCING SECTOR}

Millions of US Dollars (Current Prices) and Per cent

Developed Market Economies

\begin{tabular}{rrr} 
Year & \multicolumn{1}{l}{ GDP } & \multicolumn{1}{l}{ Agriculture } \\
& & \\
1977 & $5,039,151$ & 200,025 \\
1978 & $6,076,103$ & 244,085 \\
1979 & $6,929,688$ & 273,666 \\
1980 & $7,745,919$ & 272,753 \\
1981 & $7,830,968$ & 271,995 \\
1982 & $7,726,972$ & 260,745 \\
1983 & $8,010,869$ & 239,267 \\
1984 & $8,367,231$ & 255,910 \\
1985 & $8,743,777$ & 249,722 \\
1986 & $10,658,330$ & 300,696 \\
1987 & $12,377,760$ & 337,065 \\
1988 & $13,867,210$ & 354,943 \\
1989 & $14,320,780$ & 371,998 \\
1990 & $15,976,430$ & 404,598
\end{tabular}

Mining \&

Quarrying

107,542
126,610
168,851
240,321
272,339
256,084
245,272
246,632
240,796
197,662
216,208
227,690
236,541
259,205
Manufacturing

$1,317,597$

$1,585,296$

$1,782,431$

$1,906,216$

$1,874,588$

$1,791,069$

$1,848,360$

$1,941,996$

$1,999,436$

$2,481,473$

$2,862,481$

$3,235,197$

$3,290,287$

$3,603,232$
Services

$3,413,987$

$4,120,112$

$4,704,740$

$5,326,629$

$5,412,046$

$5,419,074$

$5,677,970$

$5,922,693$

$6,253,823$

$7,678,499$

$8,962,006$

$10,049,380$

$10,421,954$

$11,709,395$

\begin{tabular}{|ll}
\multicolumn{2}{l}{ Percent $\propto$ cop } \\
Services & \\
& \\
67.75 & 26.15 \\
67.81 & 26.09 \\
67.89 & 25.72 \\
68.77 & 24.61 \\
69.11 & 23.94 \\
70.13 & 23.18 \\
70.88 & 23.07 \\
70.78 & 23.21 \\
71.52 & 22.87 \\
72.04 & 23.28 \\
72.40 & 23.13 \\
72.47 & 23.33 \\
72.78 & 22.98 \\
73.29 & 22.55
\end{tabular}

Developing Market Economies

\begin{tabular}{llr} 
Year & \multicolumn{1}{l}{ GDP } & \multicolumn{1}{l}{ Agriculture } \\
& & \\
1977 & $1,265,145$ & 235,856 \\
1978 & $1,454,592$ & 261,909 \\
1979 & $1,731,710$ & 290,110 \\
1980 & $2,070,053$ & 320,153 \\
1981 & $2,229,044$ & 337,478 \\
1982 & $2,199,815$ & 331,255 \\
1983 & $2,130,010$ & 342,388 \\
1984 & $2,139,803$ & 355,640 \\
1985 & $2,175,990$ & 356,947 \\
1986 & $2,250,704$ & 383,835 \\
1987 & $2,505,352$ & 410,330 \\
1988 & $2,735,309$ & 451,256 \\
1989 & $3,076,729$ & 475,715 \\
1990 & $3,463,001$ & 551,127
\end{tabular}

\begin{tabular}{|c|}
\hline $\begin{array}{l}\text { Mining \& } \\
\text { Quarrying }\end{array}$ \\
\hline 158,693 \\
\hline 159,428 \\
\hline 220,334 \\
\hline 304,569 \\
\hline 298,272 \\
\hline 292,490 \\
\hline 254,479 \\
\hline 221,595 \\
\hline 213,597 \\
\hline 143,875 \\
\hline 161,056 \\
\hline 156,315 \\
\hline 171,623 \\
\hline
\end{tabular}

Percent of GDP Services Mfg

51.13

52.81

52.28

52.12

53.93

54.56

54.52

54.77

54.95

57.07

57.30

57.13

58.37

58.49
17.69

18.23

18.24

17.70

17.55

17.08

17.46

18.26

18.83

19.49

19.90

20.66

20.59

19.31

all except formerly planned economies

${ }^{b}$ GDP minus Agriculture, Mining and Quarrying, and Manufacturing

Source: United Nations (1993). 
APPENDIX TABLE B-1

\section{U.S. OUTWARD FDI STOCK, TOTAL AND IN DEVELOPING COUNTRIES}

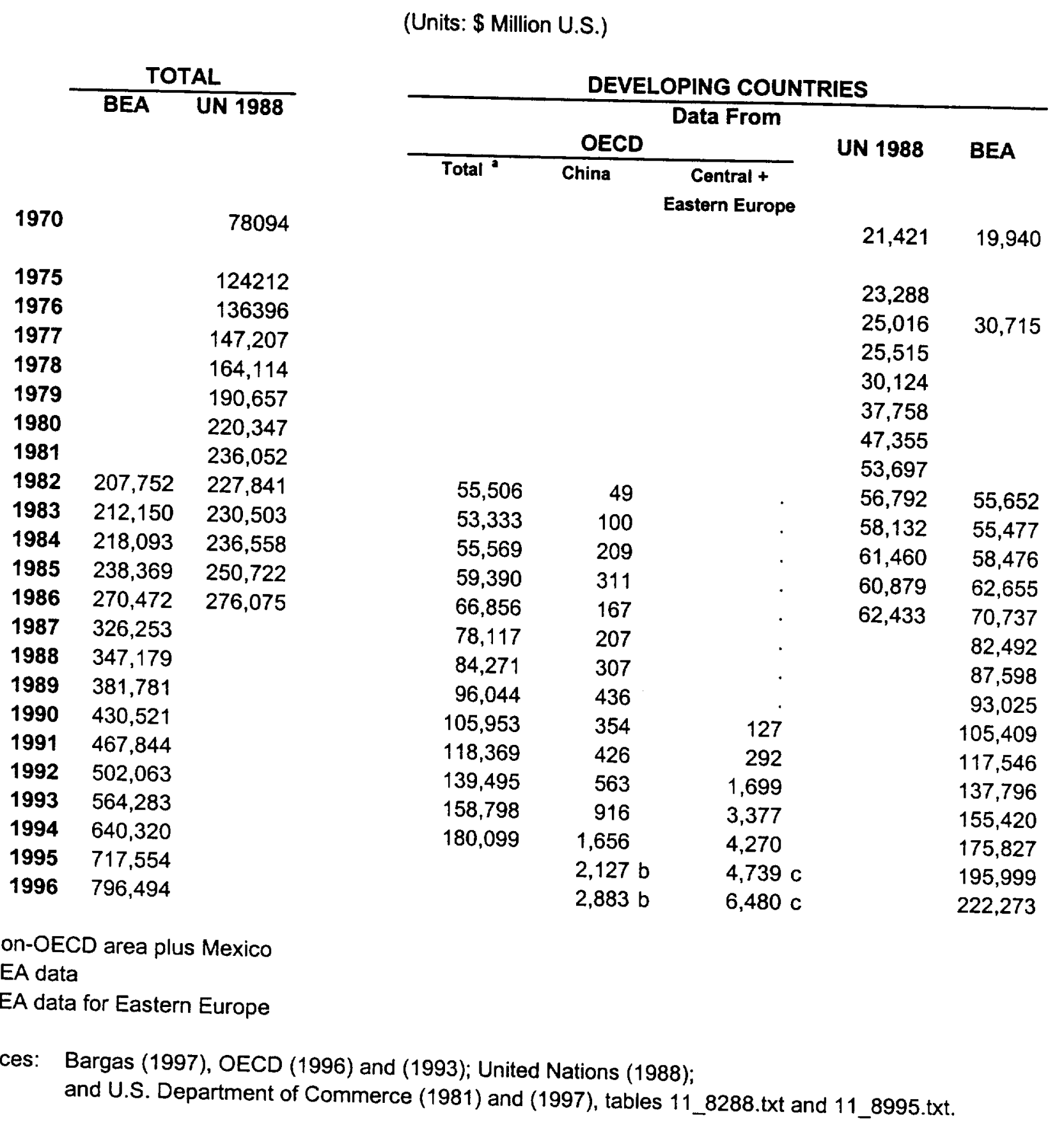


APPENDIX TABLE B-2

\section{JAPANESE OUTWARD INVESTMENT STOCK, TOTAL AND IN DEVELOPING COUNTRIES}

(Units: \$ Million U.S.)

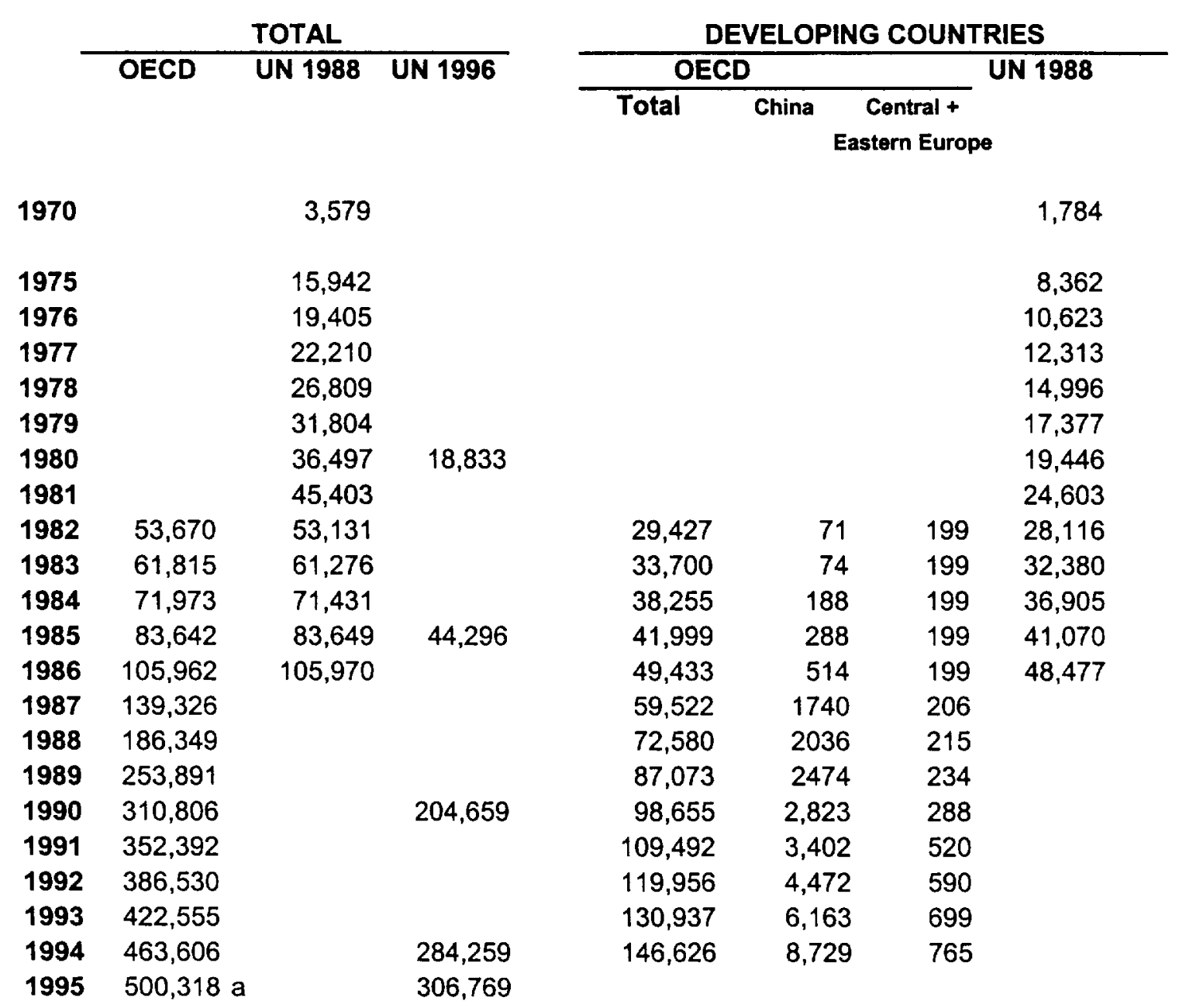

Source: OECD (1996) and (1993); United Nations (1988), (1996), and (1997).

a - Extrapolated by data from UN (1996) and (1997). 


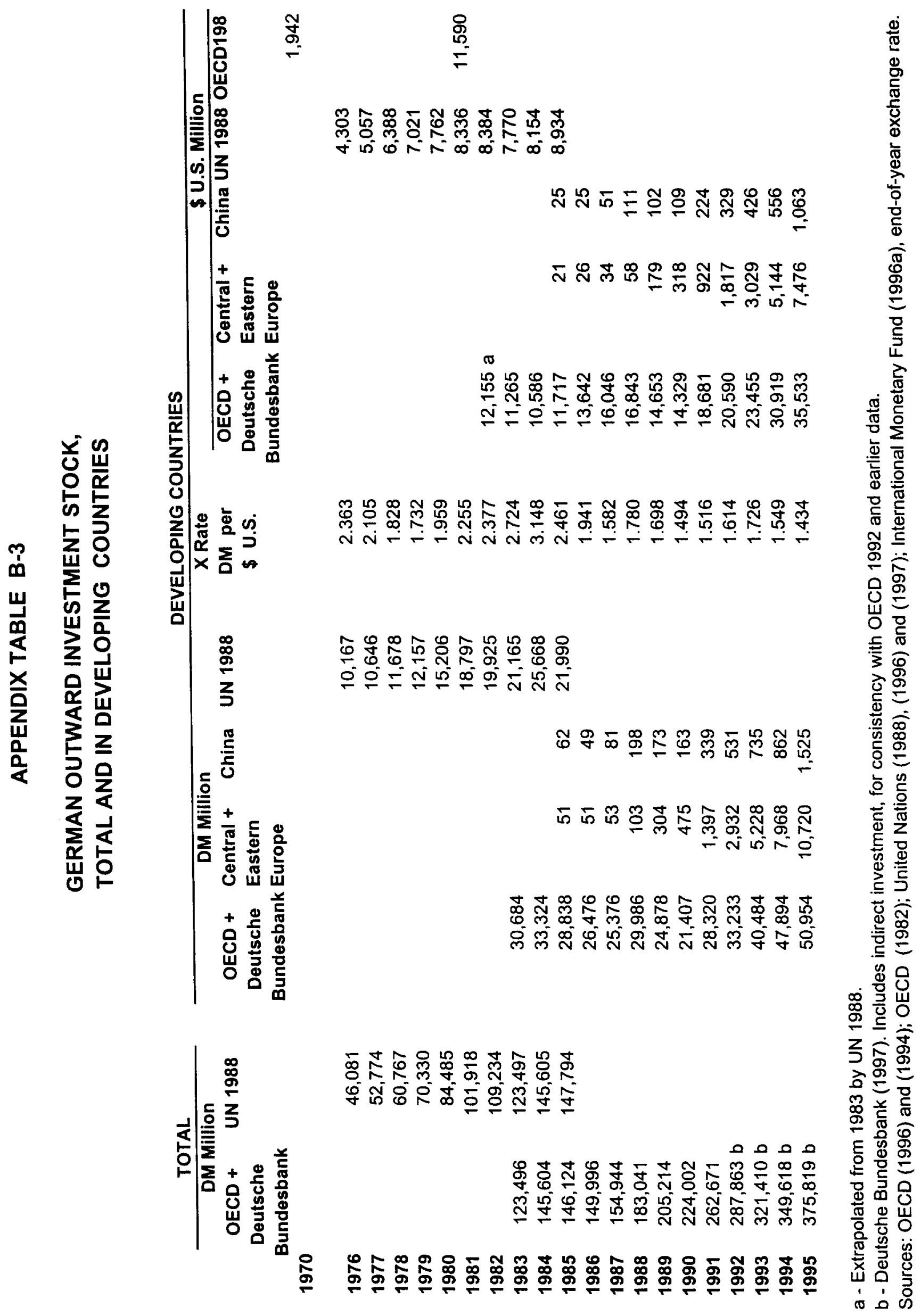




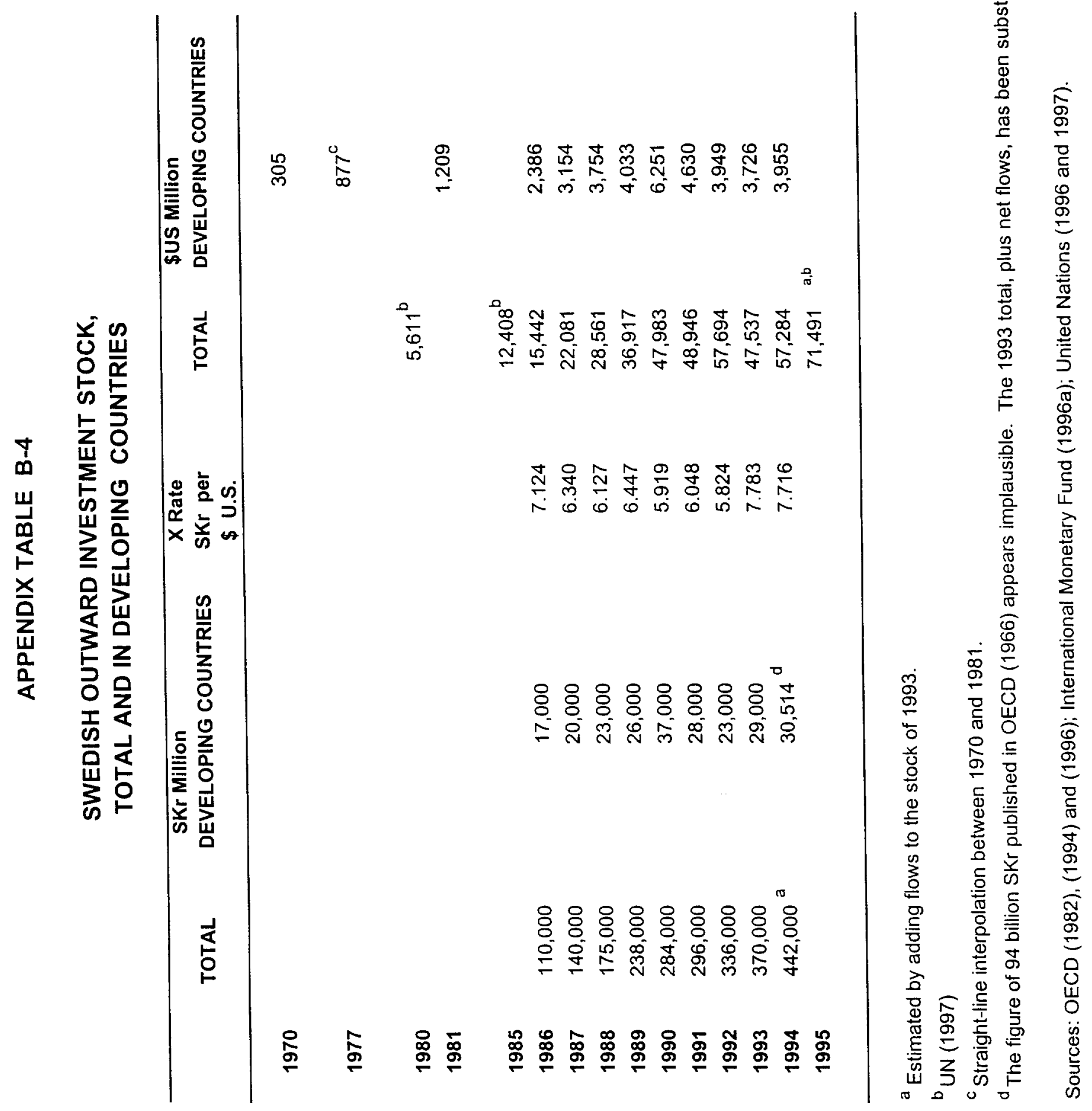


APPENDIX TABLE B-5

INWARD FDI STOCK, 1990-1995

(Units \$ Million US)

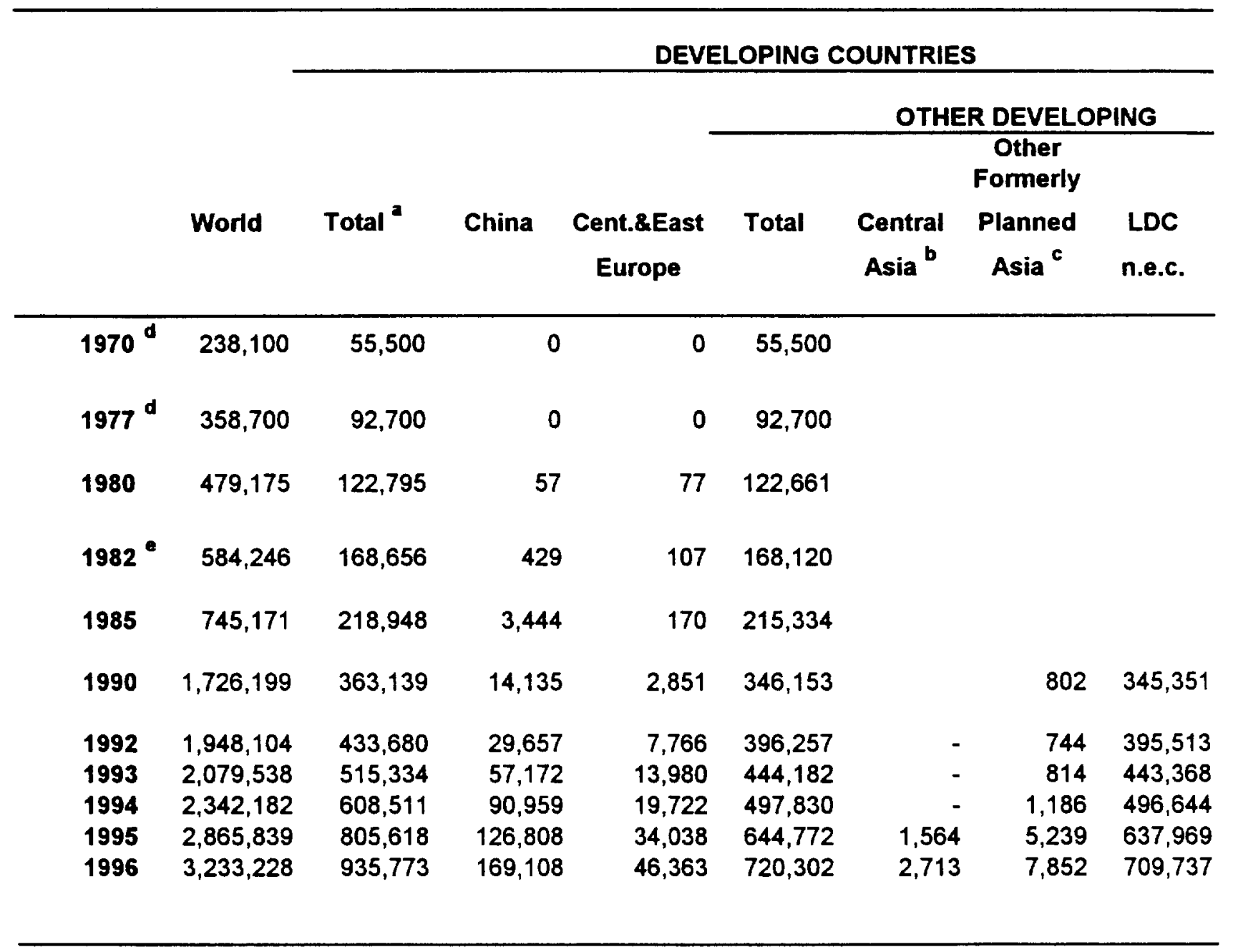

a Including Israel and South Africa

${ }^{b}$ Former Soviet Republics

${ }^{c}$ Cambodia, North Korea, Lao Republic, and Viet Nam.

${ }^{d}$ Calculated by subtracting inflows (Appendix Table B-6) from 1980 stock

Interpolated between 1980 and 1985 stocks by using cumulated flows from Appendix Table B-6, starting with 1980 stock, and interpolating ratios of cumulated to actual stock.

Source: $\quad$ Appendix Table B-6 and United Nations (1994), (1995), (1996) and (1997), Annex Table 3 


\section{APPENDIX TABLE B-6}

\section{Reported Inflows of Direct Investment \\ (\$ Billion, except as noted)}

\begin{tabular}{|c|c|c|c|c|c|}
\hline & \multirow[b]{2}{*}{ World } & \multicolumn{4}{|c|}{ DEVELOPING COUNTRIES } \\
\hline & & Total & China & $\begin{array}{l}\text { Excl. } \\
\text { China }\end{array}$ & $\begin{array}{l}\text { Poland } \\
\text { ( } \$ \text { Mill) }\end{array}$ \\
\hline 1971 & 12.1 & 2.5 & & & \\
\hline 1972 & 13.3 & 1.9 & & & \\
\hline 1973 & 16.6 & 4.3 & & & \\
\hline 1974 & 18.5 & 5.8 & & & \\
\hline 1975 & 19.6 & 8.0 & & & \\
\hline 1976 & 16.3 & 7.3 & & & \\
\hline 1977 & 24.2 & 7.4 & & 7.4 & \\
\hline 1978 & 33.2 & 10.2 & & 10.2 & \\
\hline 1979 & 38.5 & 10.6 & & 10.6 & \\
\hline 1980 & 48.8 & 9.3 & & 9.3 & 8 \\
\hline 1981 & 60.7 & 20.4 & & 20.4 & 15 \\
\hline 1982 & 51.0 & 24.7 & 0.4 & 24.3 & 13 \\
\hline 1983 & 53.9 & 17.3 & 0.6 & 16.7 & 16 \\
\hline 1984 & 63.9 & 16.8 & 1.3 & 15.5 & 28 \\
\hline 1985 & 58.0 & 14.5 & 1.7 & 12.8 & 15 \\
\hline
\end{tabular}

Source: International Monetary Fund (1992) and earlier issues. 


\section{APPENDIX TABLE B-7}

\section{FOUR COUNTRIES ^ STOCKS OF FDI IN DEVELOPING COUNTRIES SELECTED YEARS, 1970-1996}

\begin{tabular}{|c|c|c|c|c|}
\hline & \multicolumn{2}{|c|}{ All Developing Countries } & \multicolumn{2}{|c|}{$\begin{array}{c}\text { Developing Countries except } \\
\text { China and Central+Eastern Europe }\end{array}$} \\
\hline & $\begin{array}{l}4 \text { Countries' Outward } \\
\text { Investment Stock }\end{array}$ & $\begin{array}{l}\text { 4-Country Share } \\
\text { of Total Inward } \\
\text { Stock }\end{array}$ & $\begin{array}{l}4 \text { Countries' Outward } \\
\text { Investment Stock }\end{array}$ & $\begin{array}{c}\text { 4-Country Share } \\
\text { of Total Imward } \\
\text { Stock }\end{array}$ \\
\hline 1970 & 25,957 & 46.8 & 25,957 & 46.8 \\
\hline $1977^{b}$ & 43,762 & 47.2 & 43,762 & 47.2 \\
\hline $1982^{b}$ & 98,589 & 58.5 & 98,589 & 59.1 \\
\hline 1990 & 224,644 & 61.9 & 220,625 & 63.7 \\
\hline 1991 & 250,349 & & 244,563 & \\
\hline 1992 & 282,291 & 65.1 & 272,821 & 68.8 \\
\hline 1993 & 313,538 & 60.8 & 298,928 & 67.3 \\
\hline 1994 & 357,327 & 58.7 & 336,207 & 67.5 \\
\hline
\end{tabular}

aS, Japan, Germany and Sweden (assumed 0 in China and Central+Eastern Europe).

b 1978 for Sweden

Source: Appendix Tables B-1 through B-6. 


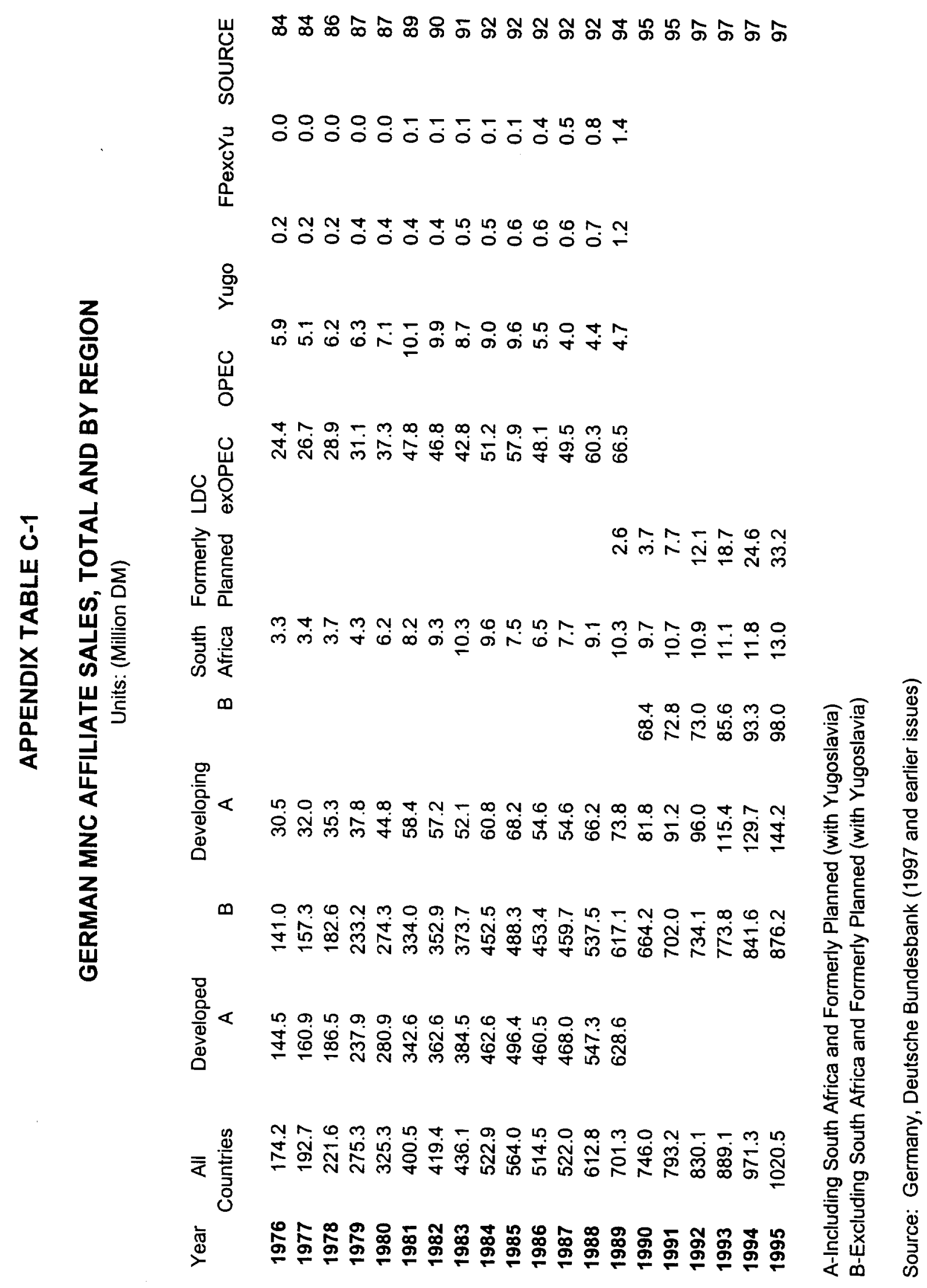




\section{APPENDIX TABLE C-2}

\section{AFFILIATE (INTERNATIONALIZED) OUTPUT, FOUR COUNTRIES, 1990-1995 \\ (Units: \$ Million)}

\begin{tabular}{|c|c|c|c|c|c|}
\hline & U.S. & Germany & Japan & Sweden & 4 Countries \\
\hline 1990 & 356,033 & 161,102 & 151,879 & 14,130 & 683,644 \\
\hline 1991 & 356,069 & 167,291 & 176,302 & $14,054^{b}$ & 713,716 \\
\hline 1992 & 361,524 & 180,009 & 180,918 & $13,979^{b}$ & 736,390 \\
\hline 1993 & 359,179 & 188,221 & $210,456^{c}$ & $13,904^{b}$ & 771,760 \\
\hline 1994 & 403,696 & 209,487 & $252,867^{c}$ & 13,828 & 879,878 \\
\hline 1995 & 462,559 & 249,232 & $292,236^{c}$ & $17,257^{a}$ & $1,021,284$ \\
\hline
\end{tabular}

b $_{\text {interpolated on a straight line. }}$

${ }^{\circ}$ Appendix Table C-6.

Sources: For the U.S., Mataloni (1995) and (1997), Mataloni and Goldberg (1994), and Mataloni and Fahim-Nader (1996); for Germany sales from Appendix Table C-1, converted into US $\$$ and multiplied by .35; For Japan, Lipsey, Blomström, and Ramstetter (1998) and Appendix Table C-6; and for Sweden, Tabulations by the Industriens Utredningsinstitut and Appendix Table C-4. 


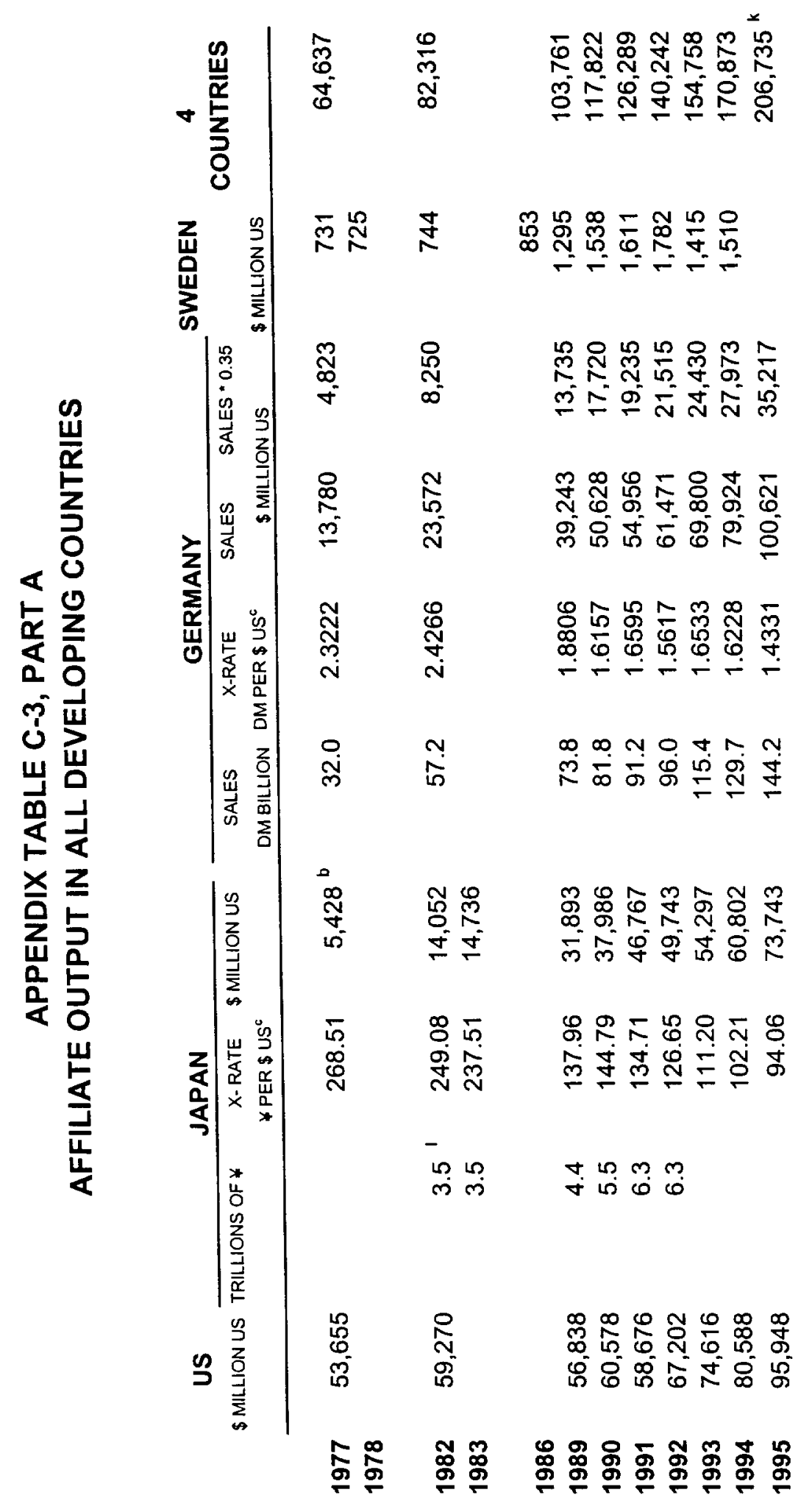




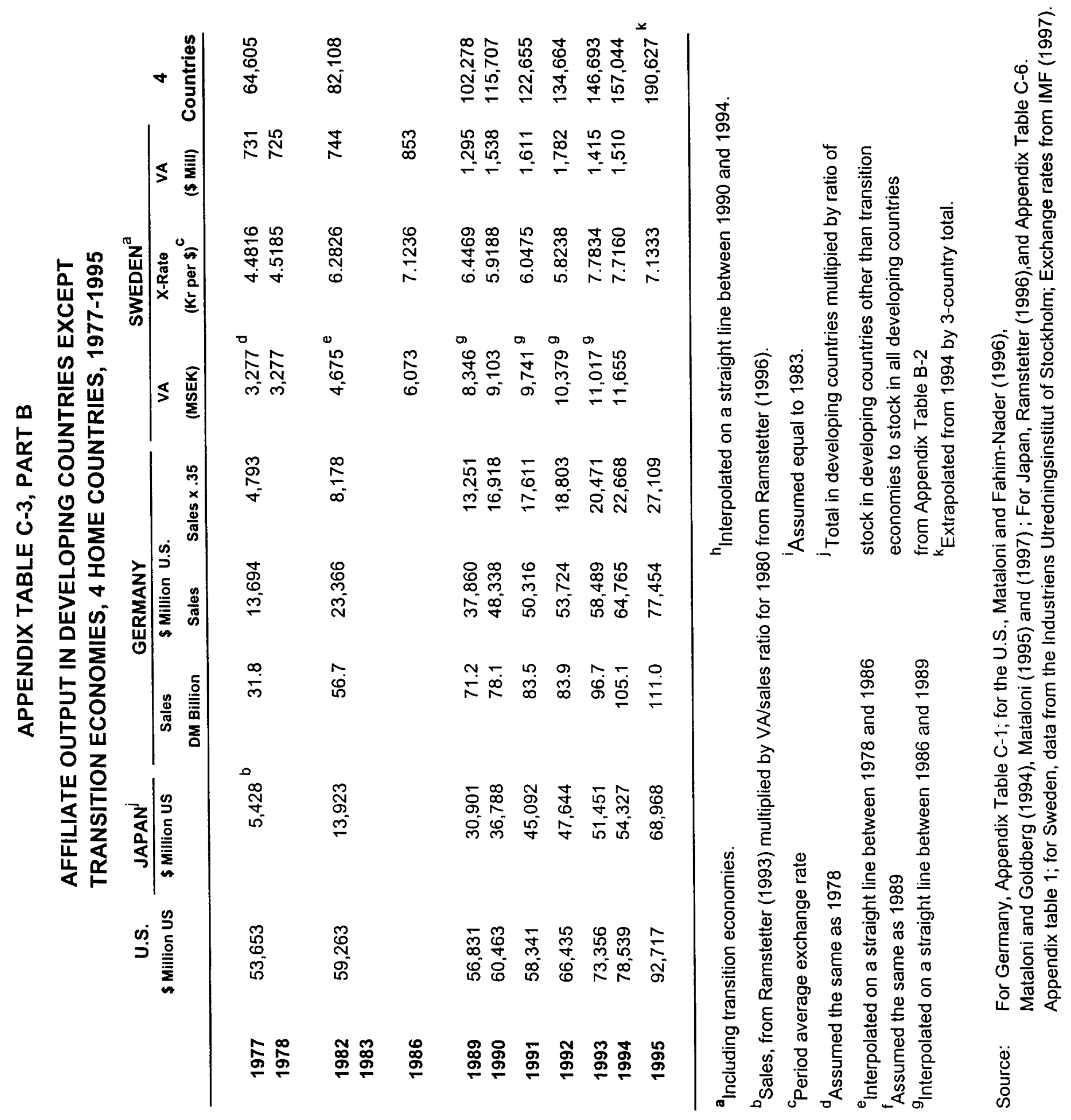




\section{APPENDIX TABLE C-4}

WORLD MANUFACTURING OUTPUT BY MNC AFFILIATES, 4 COUNTRIES

\begin{tabular}{|c|c|c|c|c|c|c|c|c|}
\hline & \multirow[b]{2}{*}{$\begin{array}{l}\text { U.S. } \\
\text { (\$ Millio }\end{array}$} & \multirow[b]{2}{*}{$\begin{array}{l}\text { Japan } \\
\text { n U.S.) } \\
\end{array}$} & \multicolumn{3}{|c|}{ Germany } & \multicolumn{2}{|c|}{ Sweden } & \multirow{2}{*}{$\begin{array}{c}4 \text { Countries } \\
\text { Output } \\
\text { on U.S.) }\end{array}$} \\
\hline & & & $\begin{array}{c}\text { Sales } \\
\text { (DM Billion) }\end{array}$ & $\begin{array}{l}\text { Sales } \\
\text { (\$ Millior }\end{array}$ & $\begin{array}{l}\text { Output }^{c} \\
\text { n U.S.) }\end{array}$ & $\begin{array}{c}\text { VA } \\
\text { (MSEK) } \\
\end{array}$ & $\begin{array}{l}\text { VA }^{\mathrm{g}} \\
(\$ \text { Millior }\end{array}$ & \\
\hline $\begin{array}{l}1977 \\
1978\end{array}$ & 71,609 & $9.363^{\mathrm{a}}$ & 105.6 & 45,474 & 15,916 & $\begin{array}{l}19,317^{d} \\
19,317\end{array}$ & $\begin{array}{l}4,310 \\
4,275\end{array}$ & 101,198 \\
\hline 1980 & & 13,516 & & & & & & \\
\hline $\begin{array}{l}1982 \\
1983\end{array}$ & 99,756 & $\begin{array}{l}13,963^{b} \\
14,187\end{array}$ & $\begin{array}{l}212.9 \\
222.2\end{array}$ & $\begin{array}{l}87,736 \\
87,025\end{array}$ & $\begin{array}{l}30,708 \\
30,459\end{array}$ & $34,416^{e}$ & 5,478 & 149,905 \\
\hline 1986 & & 35,262 & 251.7 & 115,911 & 40,569 & 49,516 & 6,951 & \\
\hline $\begin{array}{l}1989 \\
1990\end{array}$ & $\begin{array}{l}172,008 \\
187,573\end{array}$ & $\begin{array}{l}50,267 \\
68,886\end{array}$ & $\begin{array}{l}344.5 \\
362.8\end{array}$ & $\begin{array}{l}183,245 \\
224,547\end{array}$ & $\begin{array}{l}64,136 \\
78,591\end{array}$ & $\begin{array}{l}75,104^{f} \\
83,634\end{array}$ & $\begin{array}{l}14,130 \\
14,054\end{array}$ & $\begin{array}{l}300,541 \\
349,104\end{array}$ \\
\hline 1991 & 182,085 & 79,554 & 395.5 & 238,325 & 83,414 & $89,400^{h}$ & 14,783 & 359,032 \\
\hline 1992 & 181,927 & 88,760 & 404.5 & 259,013 & 90,655 & $95,166^{h}$ & 16,341 & 375,246 \\
\hline 1993 & 177,746 & 117,344 & 441.0 & 266,739 & 93,359 & $100,932^{h}$ & 13,081 & 401,530 \\
\hline 1994 & 205,208 & 145,928 & 493.0 & 303,796 & 106,329 & 106,699 & 13,828 & 471,293 \\
\hline 1995 & 232,764 & 174,512 & 514.3 & 358,872 & 125,605 & & & $548,989^{i}$ \\
\hline
\end{tabular}

${ }^{a}$ Extrapolated from 1986 by sales from Ramstetter (1993).

${ }^{b}$ Interpolated on a straight line between 1980 and 1983.

'Sales x .35.

Assumed equal to 1978 .

e Interpolated on a straight line between 1978 and 1986.

IInterpolated on a straight line between 1986 and 1990.

${ }^{9}$ Exchange Rates from Appendix Table C-3.

${ }^{\mathrm{h}}$ Interpolated on a straight line between 1990 and 1994.

'Extrapolated from 1994 by 3- country total

Sources: Same as Table C-2. 


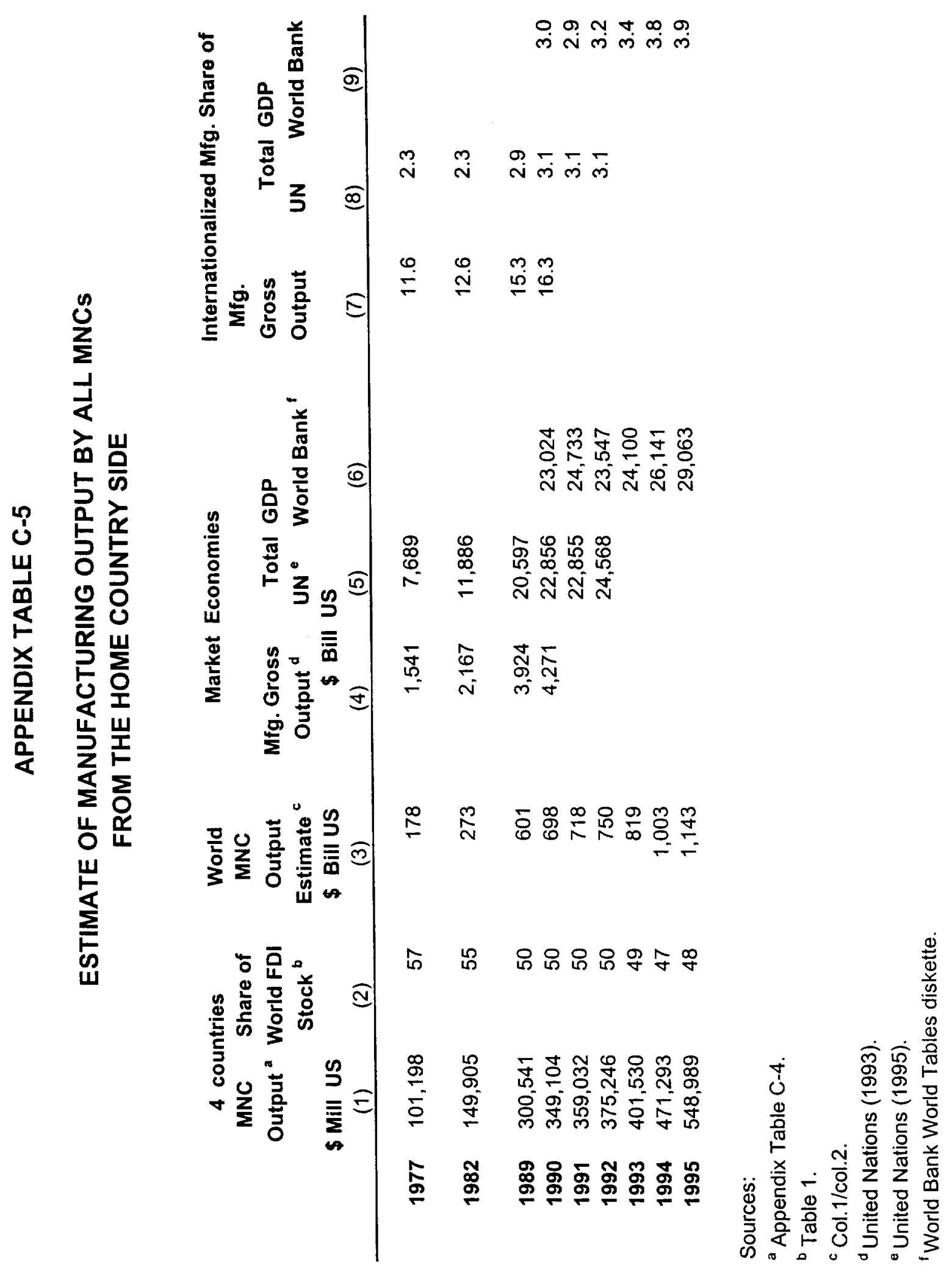




\section{APPENDIX TABLE C-6}

\section{EXTRAPOLATIONS OF JAPANESE AFFILIATE OUTPUT}

\begin{tabular}{|c|c|c|c|c|}
\hline $\begin{array}{l}\text { Total } \\
\text { of Af }\end{array}$ & $\begin{array}{l}\text { Sales } \\
\text { iliates }\end{array}$ & $\begin{array}{c}\text { Outward } \\
\text { Invest. Stock }\end{array}$ & $\begin{array}{l}\text { Ratio: Sales/ } \\
\text { Invest. Stock }\end{array}$ & Output \\
\hline$¥$ Billion $^{\text {a }}$ & $\$$ Million ${ }^{b}$ & \$ Million & & (\$ Million) \\
\hline
\end{tabular}

ALL COUNTRIES

$\begin{array}{lrrrrr}1992 & 79,007 & 624,315 & 386,530 & 1.6152 & 180,918^{d} \\ 1993 & & (738,922)^{\mathrm{e}} & 422,555 & (1.7487) & 214,130^{f} \\ 1994 & (872,599)^{\mathrm{e}} & 463,606 & (1.8822) & 252,867^{f} \\ 1995 & 94,855 & 1,008,452 & 500,318 & 2.0156 & 292,236^{f}\end{array}$

WORLD MINUS NORTH AMERICA, EUROPE, AND OCEANIA

Est. from Invest. Stock

1992 $18,777 \quad 148,376$

119,956

1.2369

$49,743^{d}$

1993

130,937

$54,297^{9}$

1994

146,626

$60,802^{g}$

1995

$28,901 \quad 307,261$

$92,178^{f}$

\section{ALL COUNTRIES, MANUFACTURING}

1992

$25,114 \quad 198,451$

$88,760^{d}$

1993

$117,344^{h}$

1994

$145,928^{h}$

1995

$36,700 \quad 390,176$

${ }^{a}$ From MITI tabulations, unadjusted.

b Translated using annual average exchange rates from Appendix Table C-3

${ }^{c}$ From Appendix Table B-2.

${ }^{d}$ From Ramstetter (1996) and Lipsey, Blomström, and Ramstetter (1998).

${ }^{e}$ Interpolated between 1992 and 1995 by outward investment stock.

${ }^{f}$ Extrapolated from 1992 by affiliate sales.

${ }^{9}$ Extrapolated from 1992 by outward investment stock.

${ }^{\mathrm{h}}$ Interpolated on a straight line between 1992 and 1995. 


\section{OUTPUT OF U.S. PETROLEUM AFFILIATES COMPARED WITH DEVELOPING COUNTRY AND MARKET ECONOMY MINING AND QUARRYING OUTPUT}

\begin{tabular}{|c|c|c|c|c|c|c|}
\hline & $\begin{array}{l}\text { U.S. Pet } \\
\text { Affiliate }\end{array}$ & $\begin{array}{l}\text { roleum } \\
\text { Output }\end{array}$ & $\begin{array}{r}\text { Market Ec } \\
\text { Mining \& } Q \\
\text { Outp }\end{array}$ & $\begin{array}{l}\text { my } \\
\text { rying }\end{array}$ & $\begin{array}{l}\text { U.S. Pet } \\
\text { Affiliate }\end{array}$ & \\
\hline & $\frac{\text { Total }}{\$ \text { Million }}$ & $\frac{\text { Developing }}{\text { US }}$ & $\frac{\text { Total }}{\$ \text { Millio }}$ & $\frac{\text { reloping }}{\mathrm{S}}$ & Total & ping \\
\hline 1977 & 62,010 & 36,595 & 266,505 & 158,693 & 23.3 & 23.1 \\
\hline 1982 & 85,608 & 30,230 & 448,574 & 292,490 & 19.1 & 10.3 \\
\hline 1989 & 77,195 & 17,960 & 408,164 & 171,623 & 18.9 & 10.5 \\
\hline 1990 & 86,987 & 21,478 & 476,765 & 217,560 & 18.2 & 9.9 \\
\hline 1991 & 88,835 & 19,398 & & & & \\
\hline 1992 & 92,526 & 20,002 & & & & \\
\hline 1993 & 91,506 & 22,072 & & & & \\
\hline 1994 & 94,005 & 19,451 & & & & \\
\hline 1995 & 100,363 & 23,438 & & & & \\
\hline
\end{tabular}

Source: Mataloni and Goldberg (1994); Mataloni (1995) and (1997);

Mataloni and Fahim-Nader (1996); and United Nations (1993). 


\section{APPENDIX TABLE C-8}

\section{OUTPUT OF U.S. MANUFACTURING AFFILIATES COMPARED WITH DEVELOPING COUNTRY AND MARKET ECONOMY MANUFACTURING OUTPUT}

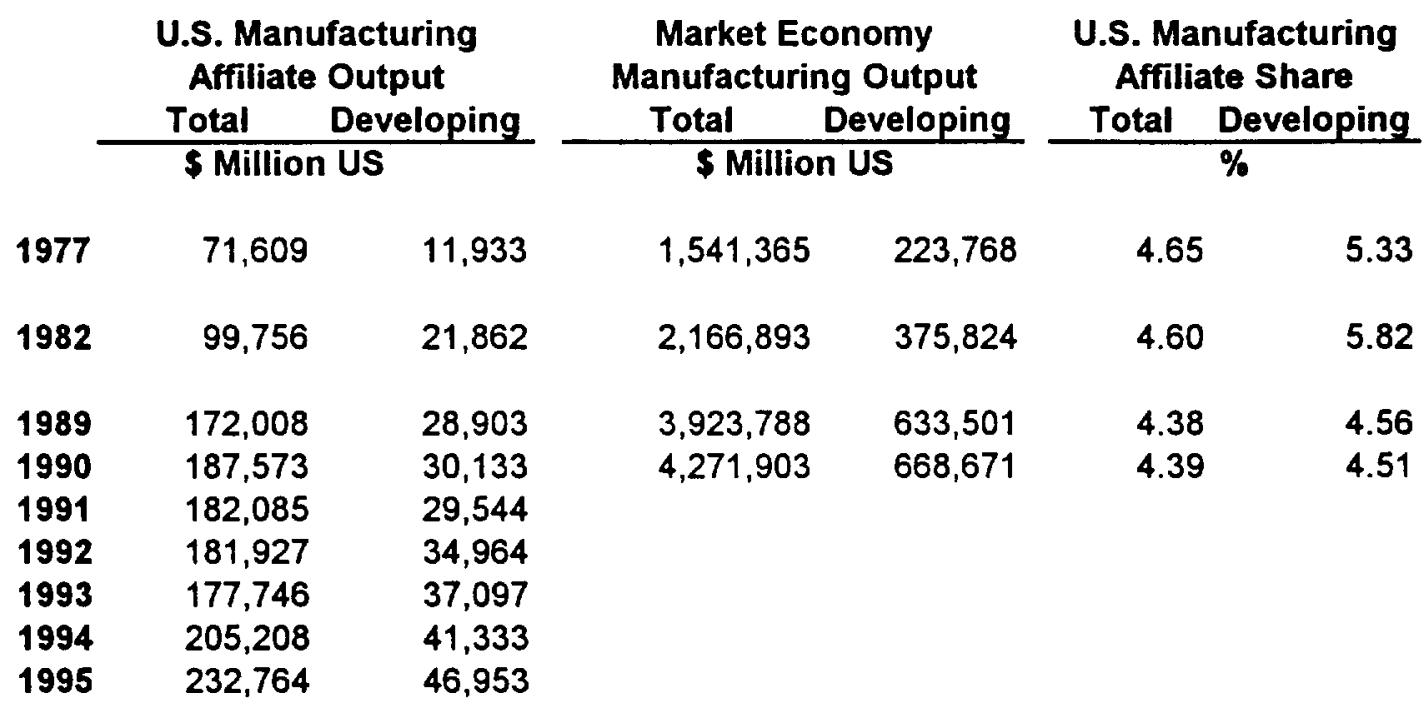

Source: Mataloni and Goldberg (1994); Mataloni (1995) and (1997);

Mataloni and Fahim-Nader (1996); and United Nations (1993). 


\section{APPENDIX TABLE C-9}

\section{OUTPUT OF U.S. AFFILIATES OUTSIDE OF PETROLEUM AND MANUFACTURING COMPARED WITH DEVELOPING COUNTRY AND MARKET ECONOMY OUTPUT OTHER THAN MINING AND MANUFACTURING}

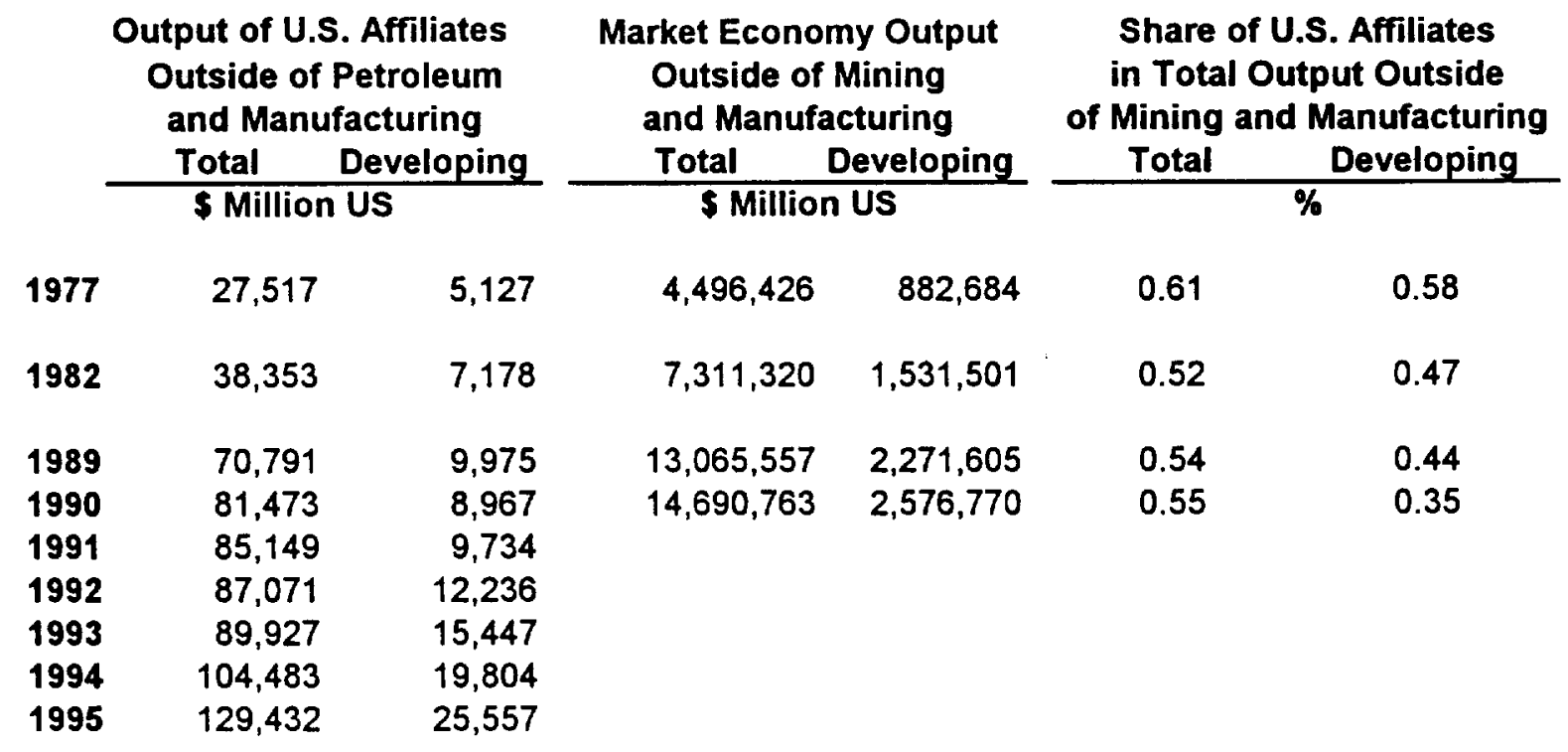

Source: Mataloni and Goldberg (1994); Mataloni (1995) and (1997);

Mataloni and Fahim-Nader (1996); and United Nations (1993). 


\section{NONMANUFACTURING NON-PETROLEUM OUTPUT BY U.S. AFFILIATES AND NONMANUFACTURING OUTPUT BY JAPANESE AND GERMAN AFFILIATES}

\begin{tabular}{|c|c|c|c|c|c|c|}
\hline & & Affili & tes of & & GDP $\mathrm{m}$ & ut in \\
\hline & U.S. & Japan & Germany & 3 Countries & Mfg.\& Min. & Min. \& A \\
\hline & & Jnits: Millic & ns of $\$ l$ & & Units: & $\$$ US \\
\hline 1977 & 27,517 & 18,518 & 12,630 & 58,665 & 4,497 & 4,060 \\
\hline 1980 & & 31,934 & & & 6,998 & 6,406 \\
\hline $\begin{array}{l}1982 \\
1983\end{array}$ & 38,353 & $\begin{array}{l}39,551^{\mathrm{a}} \\
43,360\end{array}$ & 29,783 & 97,777 & $\begin{array}{l}7,211 \\
7,421\end{array}$ & $\begin{array}{l}6,619 \\
6,839\end{array}$ \\
\hline 1989 & 70,791 & 69,230 & 66,533 & 206,554 & 13,066 & 12,218 \\
\hline 1990 & 81,473 & 82,993 & 82,511 & 246,977 & 14,691 & 13,735 \\
\hline 1991 & 85,149 & 96,748 & 83,877 & 265,774 & & \\
\hline 1992 & 87,071 & 91,249 & 89,354 & 267,674 & & \\
\hline 1993 & 89,927 & 93,112 & 94,862 & 277,901 & & \\
\hline 1994 & 104,483 & 106,939 & 103,158 & 314,580 & & \\
\hline 1995 & 129,432 & 117,724 & 123,627 & 370,783 & & \\
\hline
\end{tabular}

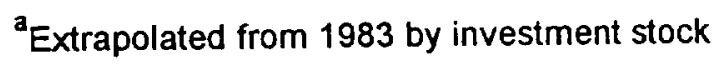

Source: Appendix Tables C-2, C-4, C-7, Lipsey, Blomström, and Ramstetter (1998), and United Nations (1993). 